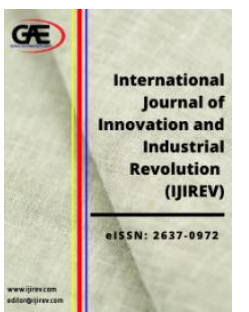

\author{
INTERNATIONAL JOURNAL OF \\ INNOVATION AND \\ INDUSTRIAL REVOLUTION \\ (IJIREV) \\ WWW.ijirev.com
}

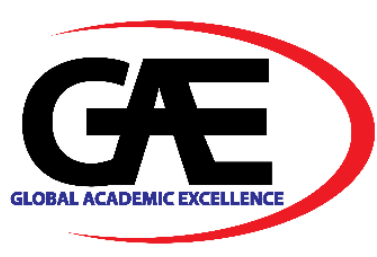

\title{
HETEROGENEOUS EFFECT OF SECTORAL COMPOSITION ON THE GREEN TECHNOLOGY INNOVATIONS IN ASIA'S MIDDLE-INCOME COUNTRIES
}

\author{
Jain Yassin ${ }^{1 *}$, Wong Sing Yun ${ }^{2}$, Herniza Roxanne Marcus ${ }^{3}$ \\ 1 Faculty of Business and Management, Universiti Teknologi Mara (UiTM) Sabah Branch, Kota Kinabalu Campus, \\ Malaysia \\ Email: jainyassin@uitm.edu.my \\ 2 North Borneo University College (NBUC), Sabah, Malaysia \\ Email: wongchristina56@gmail.com \\ 3 Faculty of Business and Management, Universiti Teknologi Mara (UiTM) Sabah Branch, Kota Kinabalu Campus, \\ Malaysia \\ Email: herniza593@uitm.edu.my \\ Corresponding Author
}

\section{Article Info:}

Article history:

Received date: 21.02 .2021

Revised date: 15.03 .2021

Accepted date: 28.03.2021

Published date: 31.03 .2021

\section{To cite this document:}

Yassin, J., Wong, S. Y., \& Marcus, H. R. (2021). Heterogeneous Effect of Sectoral Composition on The Green Technology Innovations in Aisa's Middle-Income Countries. International Journal of Innovation and Industrial Revolution, 3 (6), 1326.

DOI: 10.35631/ IJIREV.36002

This work is licensed under CC BY 4.0

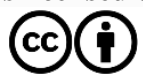

Abstract:

This study examines the extent to which sectoral composition can affect green technology innovations in 20 selected Asia's Middle-Income countries from 1995 until 2016. To measure the cross-sectional dependence among crosssectional units and allows heterogeneous coefficients in a panel, this study will adopt the Dynamic Common Correlated Effect (DCCE). The results show that an increase in the proportion of industry and services sectors plays an important role in innovations of environmentally friendly technology. It is also knowing that the tourism sector and pollution level would be a prospect for green technology innovations. On the contrary, the increasing proportion of the agriculture sector may hinder green innovations. The finding of this study can be helpful for policymakers in middle-Income countries to promote a balance of green technology development in each sector for the sake of comprehensive sustainable development.

Keywords:

Sectoral Composition, Green Technology Innovations, Dynamic Common Correlated Effect, Sustainable Development 


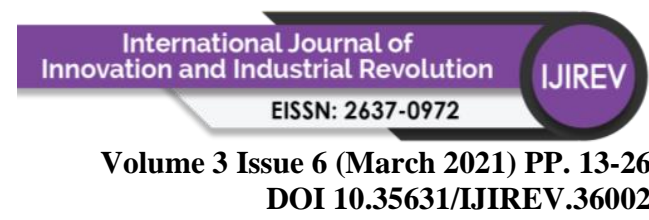

\section{Introduction}

There have been calls for cleaner and energy-efficient technologies to be used in tackling climate change and global warming. The International Energy Agency (IEA) had pointed out the shortcomings in the adoption of future sustainable energy systems and declared that the path towards achieving sustainable energy remains to be extremely slow (Chakraborty and Mazzanti, 2020). In many middle-income countries, there had been a lack of clean energy available. This increased the reliance on fossil fuel consumption, creating an issue of energy insecurity. This issue of consumption would have a direct or indirect effect on human health and could cause air pollution through the release of greenhouse gas. Hence, Taghizadeh-Hesary et al. (2020) recommended that diversification of energy in middle-income countries from reliance on fossil fuel consumption to a more renewable energy source consumption is necessary to reduce the negative repercussions. This would therefore improve energy security by increasing access to renewable energy. Renewable energy is considered an important mechanism for achieving sustainable development.

The energy demand has been growing rapidly in the Asian region as it becomes a hub of economic growth and development. This could be the underlying reason that explains why the Asian region was found to be among the world's top regions for Carbon dioxide (CO2) emission. About half of the global $\mathrm{CO} 2$ emissions were found to come from this region (Saleem et al., 2019). The $\mathrm{CO} 2$ emission leads to global warming and climate change that would be detrimental to the global ecosystem. The impact of urbanization on emissions is found to be even more pronounced in the middle-income group (Poumanyvong and Kaneko, 2010). As such, access to renewable energy sources will be crucial to attaining sustainable economic growth and improving environmental conditions. Furthermore, a carbon-free economy requires more renewable energy technologies. This implies that investment or green financing on energy-based technological innovation is required to improve the efficiency of energy. Many of the works of literature (see Anderson and Karpestam, 2012; Narayan and Smyth, 2008; Wang et al.,2011) had supported that a reduction in CO2 emissions without utilizing low carbon technologies will not help in achieving sustainable economic growth. Besides, the Asian economies have been known to produce less renewable energy compared to other economies (Usman et al., 2020).

It is paramount to point out that middle-income countries are currently undergoing massive structural changes towards more industrialized economies. Over the past three decades, the economic significance of middle-income countries is growing in the global paradigm (Sohag et al., 2017). There has been a rapid transformation of economies from the primary agricultural sector to the energy-led industrial sector in these middle-income countries. This leads to an unprecedented increase in global energy consumption which generates additional $\mathrm{CO} 2$ emissions. Encouraged by this thought, past works of literature such as Mills and Schleich (2012) and Faiers et al. (2007) advocated that technological sophistication and energy-efficient technology adoption are crucial to be undertaken in minimizing the adverse effect of the increasing energy consumption due to fast-changing structural transition of middle-income economies. This is further supported by the ecological modernization theory which postulated that advanced market societies can improve resource efficiency through technological innovations. Findings by Sohag et al. (2017) offered empirical support that the efficiency in energy use should be prioritised to reduce $\mathrm{CO} 2$ emission for middle-income countries. Besides, massive improvements in the efficiency of technologies would facilitate reductions in quantity energy required for production in economies (Tatsutani, 2009). 


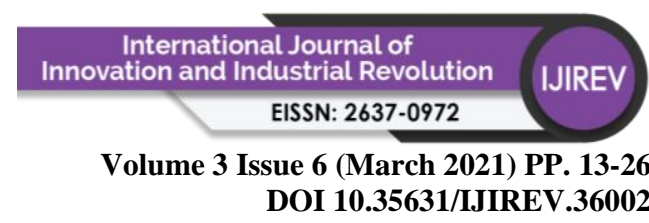

Furthermore, middle-income countries are still lacking technological sophistication and have a weak adoption of technology that supports a carbon-free economy (Yanikkaya, 2003). The focus on middle-income countries is well-justified since high-income countries do not face the problem of being less equipped and less technologically efficient in dealing with $\mathrm{CO} 2$ emissions. Meanwhile, low-income countries do not contribute significantly to the global share of $\mathrm{CO} 2$ emission as compared to middle-income countries. Hence, it would be less significant for the study to focus on high-income or low-income countries. With higher economic growth rates, emerging Asia is increasingly moving towards becoming a middle-income region. This fast-paced economic growth has been accompanied by high energy consumption (Asia Development Bank Institute, 2012). Therefore, it is imperative that these countries would need to improve on energy efficiency and green technology innovation. The choice of the study is focusing on the middle-income countries from Asia can also be attributed to the recent economic growth in the Asian region, its high population, and the issue of energy poverty (Maslyuk and Dharmaratna, 2013). Besides, a middle-income country has a better position to afford the development of green technological innovation.

The voluminous studies in the strand that focus on the relationship between energy consumption, economic growth, and emissions of greenhouse gases had indicated the importance of the development of green technology innovations that help in improving energy efficiency as the main key to emissions mitigation strategies (see Yin et al., 2018; Meirun et al.,2020). The development and deployment of beneficial technologies across all sectors will be needed to accelerate green growth (Asia Development Bank Institute, 2012). However, it would be necessary to analyse the factors that could have effects on green technology innovation before the development and diffusion of technological innovations can take place. In this context, the empirical analysis had been relatively scarce and unexplored. This motivated our study to examine such effects on green technology innovations. In particular, this study will analyse the sectoral composition heterogeneous effect on green technology innovation. This will address the issue concerning past pieces of literature that had largely ignored the importance of heterogeneity when examining the panel data (Wang et al., 2016). This study also seeks to fill the gaps in previous literature in examining a cross-country effect. The objective of this paper is therefore to examine the sectoral composition heterogeneous effect on green technology innovations in 20 selected Asia's middle-income countries from 1995 until 2016.

The novel empirical findings will indicate the effects which vary according to sectoral composition. To examine the heterogeneity effects among the different sectors, the dynamic common correlated effects estimators will be employed in this paper. Findings from this paper will extend the existing literature and of special interest to policymakers. The nexus established between the sectoral composition and green technology innovations will be useful to help countries in achieving the Sustainable Development Goals (SDGs). Various supportive policies may be needed to ease access to green energy in line with the SDGs (Taghizadeh-Hesary and Rasoulinezhad, 2020). The achievement is not possible if countries have limited access to cleaner and efficient energy. The development of green energy innovation will also contribute to supporting job creation, overcoming poverty, and enhance economic growth (Karekezi et al., 2012). Although the middle-income Asian countries had been undergoing a fast-sectoral transformation over the recent years, however, the potential in the region had remains untapped. Hence, the examination of the sectoral composition heterogeneous effect on the green technology innovation will be highly significant. Moreover, this region has the chance 


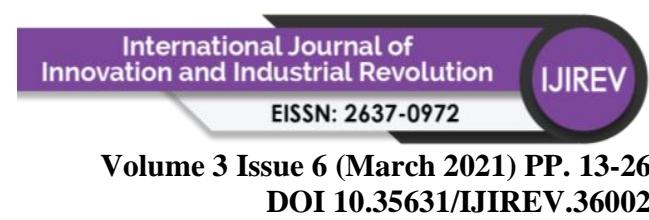

to position itself as a front-runner in low-carbon green innovation, to become the most energy and resource-efficient region in the world which further strengthens its global competitiveness (Asia Development Bank Institute, 2012). Hence, successful implementation of green innovation will certainly become a key driver for growth and development

\section{Literature Review}

There are various literatures related to the sectoral composition impact on green technology innovation, so the conclusion from the findings also varies among the researchers. The results also different in terms of the region, the variables selected, and methodology. In our study, we will take into consideration the sectoral composition effect which divides into the agricultural sector, industry, and service sector. In the last decade or so, green innovation has gained interest among researchers and practitioners. Some of the literature discussed the effect of a single sector on green technology innovation while some studied the effect of various sectors on it. Green innovation appeared to be a significant impact factor of forming a resourceefficient and environmentally friendly society for sustainable development (Yin et al., 2018).

The nature of the relationship between economic growth and green technology innovation has been studied by several studies. Meirun et al. (2020) in their study of Singapore employed the novel bootstrap autoregressive-distributed lag (BARDL) technique using time series data from 1990 to 2018. Based on their study, there is a positive and significant relationship between green technology innovation with economic growth in both the long run and short run. In addition to this, a similar result was found by Belin et al. (2011).

Although the changes in the sectoral composition generally known to associated with economic growth, to date, studies that examine the direct effect of sectoral composition on green technology innovation only is extremely limited. Nonetheless, the significance of sectoral shares on green technology innovation is highlighted by few studies. According to Karlsson and Hovelsrud (2021), in Norway, practitioners within the fisheries and agricultural sectors promote their activities and products as sustainable and as an important part of a green transformation. By doing so, the narratives are not transformational but rather ensure a continuation of current practices with incremental adjustments that may contribute to environmental sustainability. Peng et al. (2020) claimed that the green technology development of the manufacturing industry in Jiangsu province has been constantly improving during 20122016. Moreover, studies such as Lin and Ho (2008), Murshed et al. (2020), and Yassin and Aralas (2020) suggested that the industry and services sector can improve environmental quality from the adoption of green technology innovation.

In terms of other determinants, Bai et al. (2019) found that R\&D grants have improved the green innovation in 527 energy-intensive companies over the sample period 2010-2015 in China. Meanwhile, Yii and Geetha (2017) found that technology innovation is negatively related to $\mathrm{CO} 2$ emissions in the short-run in Malaysia. Urbanization also claimed to have an adverse effect on eco-efficiency and innovation (Zhou et al.,2020). In terms of tourism, Gavrilovic \& Maksimovic (2018) claimed the tourism sector has the potential to significantly promote green technology. 


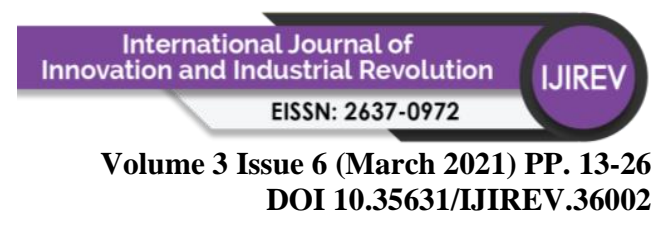

\section{Methodology}

\section{Model Construction and Data}

This study used the annual data in 20 selected Asia's Middle-Income countries from 1995 until 2016. The country selection was based on its current state as emerging economies and the availability of data on green technology innovation which is the dependent variable. To assess the extent to which sectoral composition can affect green technology innovations, first, this study divided the economic effects into three sectors: agriculture (primary), industry (secondary), and services (tertiary). The is accordingly the three-sector model developed by Fisher (1935) and adopted by numerous researchers (see Dogan \& Inglesi-Lotz, 2020; Gryshova et al.,2020). The study's variables also included tourist arrivals, environmental degradation ( $\mathrm{CO} 2$ emissions), and urban population. Thus, this study developed the econometric model as follows:

$$
\text { GTech }=f(A G R I, I N D U, S E R V, T A, C O 2, U R B)
$$

Equation (1) indicates a green technology innovation (GTech) which depending on agriculture output (AGRI), industry output (INDU), services output (SERV), tourism arrivals (TA), carbon emissions (CO2), and urban population (URB). The description for each variable used is given in Table 1. Next, taking natural logarithms of equation (1) and transform it into a linear specification in a dynamic panel as follow.

$$
\begin{aligned}
\text { InGtech }_{i t}= & \beta_{0} \text { InGtech }_{i t-1}+\beta_{1} \ln A G R I+\beta_{2} \operatorname{InINDI}_{i t}+\beta_{3} \ln S E R V_{i t}+\beta_{4} \operatorname{lnT} A_{i t}+\beta_{4} \ln C O 2_{i t}+ \\
& {\ln U R B_{i t}+\lambda_{i} f_{t}+\varepsilon_{i t}}
\end{aligned}
$$

Where the $i=1 \ldots \mathrm{N}$, and $\mathrm{t}=1 \ldots \mathrm{T}$ denotes the cross-section and times of the panel respectively. To estimate the dynamic effects and heterogeneity across countries, the lagged value of green technology innovation is included in the equation. Meanwhile, the error term $\left(e_{i t}\right)$ capturing the unobserved country-specific effect $\left(f_{t}\right)$ that includes the individual heterogeneity factor

\begin{tabular}{|c|c|c|c|}
\hline $\begin{array}{c}\text { Variabl } \\
\text { e }\end{array}$ & Data Description & $\begin{array}{c}\text { Unit of } \\
\text { Measurement }\end{array}$ & Source \\
\hline GTech & $\begin{array}{l}\text { Patents in environment-related } \\
\text { technologies }\end{array}$ & $\begin{array}{l}\text { the output of } \\
\text { environmental } \\
\text { innovation }\end{array}$ & $\begin{array}{ll}\text { OECD } & \text { statistics } \\
\text { database } & \end{array}$ \\
\hline AGRI & $\begin{array}{l}\text { Share of the Agriculture sector's } \\
\text { value-added in the Gross Domestic } \\
\text { Product (GDP) }\end{array}$ & $\%$ of GDP & $\begin{array}{l}\text { World } \\
\text { Development } \\
\text { Indicators }\end{array}$ \\
\hline INDU & $\begin{array}{l}\text { Share of the industry sector's value- } \\
\text { added in the Gross Domestic Product } \\
\text { (GDP) }\end{array}$ & $\%$ of GDP & $\begin{array}{l}\text { World } \\
\text { Development } \\
\text { Indicators }\end{array}$ \\
\hline SERV & $\begin{array}{l}\text { Share of the services sector's value- } \\
\text { added in the Gross Domestic Product } \\
\text { (GDP) }\end{array}$ & $\%$ of GDP & $\begin{array}{l}\text { World } \\
\text { Development } \\
\text { Indicators }\end{array}$ \\
\hline TA & $\begin{array}{l}\text { Tourism arrivals measure the number } \\
\text { of tourists who travel aboard from a } \\
\text { country to another country. }\end{array}$ & $\begin{array}{l}\text { Number } \\
\text { international } \\
\text { arrivals }\end{array}$ & $\begin{array}{l}\text { World } \\
\text { Development } \\
\text { Indicators }\end{array}$ \\
\hline
\end{tabular}
loadings $\left(\lambda_{i}\right)$ and the remaining disturbance term $\left(\varepsilon_{i t}\right)$.

Table 1: Description and Unit of the Data 


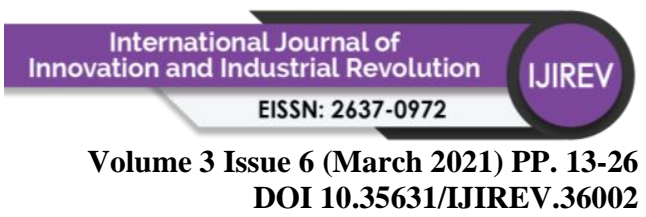

$\mathrm{CO} 2$ Carbon dioxide emissions are those stemming from the burning of fossil fuels and the manufacture of cement.

a metric ton of per capita

The Emissions

Database for

Global

Atmospheric

Research

(EDGAR)

URB People living in urban areas as defined by national statistical offices.

Ratios of urban to

World

the total Development

population Indicators

Although considerable research has been devoted to economic growth and green technology innovation, however, less attention has been paid to the effects of the sectoral composition of the economy on green technology innovation. As economic growth assumes to motivated more green technology innovations (see Belin et al.,2011) each sector is expected to have a positive sign. Meanwhile, tourism arrivals are expected to have a negative sign as according to Liu et al. (2017) tourism development harms the environment. Next, following Lin and Zhu (2019), carbon emission is expected to have a positive sign. Lastly, urbanization is also expected to have a positive sign as according to urban environmental transition, where high urbanization will motivate society to be more aware of protecting the environment and induce more demand for greener technology (Poumanyvong \& Kaneko, 2010)

\section{Testing Slope Homogeneity and the Cross-Sectional Dependency}

One of the problems in the panel statistical analysis is the existence of a heterogeneous slope. Thus, the estimation starts with testing the serial correlation using the Wooldridge test and the presence of heteroscedasticity using the modified Wald test as reported in Table 2. The results conclude there is a cross-sectional dependence among ASEAN countries. Besides, the error structure is assumed to be heteroskedastic and auto-correlated due to the possible correlation between the groups (Hoechle, 2007). The error structure is assumed to be heteroskedastic and auto-correlated due to possibly correlated between the groups. Second, the results from the panel unit root test using the Pesaran (2007) CIPS test revealed that there are mixed results at level. At first different all variables were found to be stationary. These results implied that any possible shock affecting the series is only a temporary effect.

Table 2: Serial Correlation, Cross-Sectional Dependency Test, Testing of Slope Homogeneity and Unit Root Test

\begin{tabular}{|c|c|c|c|c|c|}
\hline & \multirow[t]{3}{*}{ CD test } & \multicolumn{4}{|c|}{ CIPS } \\
\hline & & \multicolumn{2}{|c|}{ CIPS without trend } & \multicolumn{2}{|c|}{ CIPS with trend } \\
\hline & & Level & 1st Diff & Level & 1st Diff \\
\hline lnGTech & $12.5 *$ & -1.686 & $-5.187 * * *$ & $-3.282 *$ & $-5.230 * * *$ \\
\hline lnAGRI & $7.20^{*}$ & $-2.456^{*}$ & $-4.627 * * *$ & $-2.903 * *$ & $-4.642 * * *$ \\
\hline $\operatorname{lnINDU}$ & $6.22 *$ & -3.095 & $-5.187 * * *$ & $-3.578 *$ & $-5.292 * * *$ \\
\hline lnSERV & $18.42 *$ & -3.538 & $-3.579 * * *$ & -1.754 & $-4.856 * * *$ \\
\hline $\ln \mathrm{TA}$ & $14.39 *$ & $-2.554 *$ & $-5.286 * * *$ & $-3.191 *$ & $-5.391 * * *$ \\
\hline $\operatorname{lnCO} 2$ & $9.44 *$ & $-0.765 *$ & $-2.838 * * *$ & -1.797 & $-3.335 * * *$ \\
\hline $\operatorname{lnURB}$ & $14.50 *$ & -3.305 & $-5.993 * * *$ & -3.826 & $-6.035 * * *$ \\
\hline $\begin{array}{l}\text { Modified } \\
\text { Wald }\end{array}$ & $4014 * * *$ & & & & \\
\hline
\end{tabular}




\section{Wooldridge $3594.64 * * *$ \\ test}

Notes: CIPS test developed with the command of xtcips of stata 14 with 3 maximum lags; the critical value for CIPS statistics at $(* * *) 1$ percent, $(* *) 5$ percent, and $(*) 10$ percent level. The null hypothesis is that the variable is homogeneous non-stationary

\section{Dynamic Common Correlated Effects (DCCE)}

This study resort to the Dynamic Common Correlated Effects (DCCE) estimator which considers heterogeneous coefficients as developed by Chudik and Pesaran (2015). The motivation behind this estimator selection due to the heterogeneity that may exist among Asia's Middle-Income countries. This estimator provides clearer insight of the presence of unknown types of error cross-section dependence due to common stock and interdependencies, heterogeneity among the sample, and endogeneity from dynamic panel settings. To make it short, lets the model simplify as in equation 3 .

Where,

$$
y_{i t}=\alpha_{i}+\lambda_{i} y_{i t-1}+\beta_{i} x_{i t}+\sum_{\iota=0}^{p T} \delta_{i \iota \bar{z}_{t-1}}^{\prime}+\varepsilon_{i t}
$$

$\bar{z}_{t}=\left(\bar{y}_{t}, \bar{y}_{t-1}, \bar{x}_{t}\right)$

$p T$-The number of lags $(p T=\sqrt[3]{T})$

$\lambda_{i}$ - individual heterogeneity factor loading

$\beta_{i}$-the heterogeneous coefficient and randomly distribute around common mean

$\beta_{i}=\beta+v_{i}, v_{i} \sim \operatorname{IID}\left(0, \Omega_{V}\right)$

From equation $3, \lambda_{i}$ and $\beta_{i}$ are stacked into $\pi_{i}=\left(\lambda_{i t}, \beta_{i}\right)$. The mean group coefficient estimates as in equation 4 :

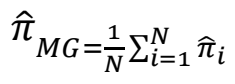

Where $\hat{\pi}_{i}$ and $\hat{\pi}_{M G}$ are consistently estimated with convergence rate $\sqrt{N}$ if $(N, T, p T) \Rightarrow \infty$. The asymptotic variances can be consistently under the full rank of factor loading estimation by:

$$
\operatorname{Var}\left(T_{M G}\right)=N^{-1} \sum_{\pi}^{\wedge}=\frac{1}{N(N-1)} \sum_{i=1}^{N}\left(\hat{\pi}_{i}-\hat{\pi}_{M G}\right)\left(\hat{\pi}_{i}-\hat{\pi}_{M G}\right)^{\prime}
$$

The mean group estimates have the following asymptotic distribution:

$$
\sqrt{N}\left(\hat{\pi}_{M G}-\pi\right) \stackrel{d}{\rightarrow} N\left(0, \sum_{M G}\right)
$$

Besides, the dynamic common correlated effect allows for Pooled Mean Group (PMG) estimations within the dynamic setting. According to Pesaran et al. (1999), the PMG estimators are the intermediary between heterogeneous and homogenous coefficients. This estimator will control the dependency by adding cross-sectional means and lags. Furthermore, this estimator able to calibrate a small sample times series bias using the jackknife correction method and the recursive mean adjustment proposed by Chudik and Pesaran (2015). The mean group estimate of the Jackknife bias-corrected DCCE estimators as follows:

Where:

$$
\hat{\pi}_{M G}=2 \hat{\pi}_{M G}-\frac{1}{2}\left(\hat{\pi}_{M G(a)}+\hat{\pi}_{M G(b)}\right)
$$

$\hat{\pi}_{M G(a)}$-Mean group estimate of the first half $\left.\left(\mathrm{t}=\frac{T}{2}+1, \ldots, T\right)\right)$

$\hat{\pi}_{M G(b)}-$ Mean group estimate of the second half $\left(\mathrm{t}=1 \ldots \frac{T}{2}\right)$ 


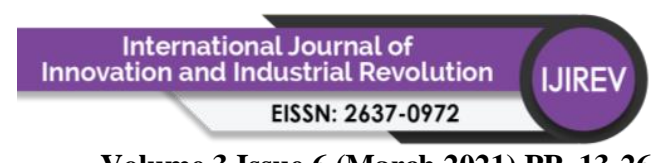

Volume 3 Issue 6 (March 2021) PP. 13-26

DOI 10.35631/IJIREV.36002

The Jackknife derived by first, estimating the first half of the existing period $\left(\hat{\pi}_{M G(a)}\right)$ and the second half $\left(\hat{\pi}_{M G(b)}\right)$ separately then taking the average value of the Mean Group Dynamic Common Correlated Effect. Interestingly, the estimation also generates cross-sectional dependence (CD) test. The employment of the Dynamic Common Correlated Effects (DCCE) model due to several reasons.

\section{Results}

The estimate results using the Dynamic Common Correlated Effects (DCCE) estimators in 20 selected Asia's Middle-Income countries from 1995 until 2016 are presented in Table 3. The results of estimations using Mean Group Dynamic Common Correlated Effect (MG-DCCE) and also taking account the estimations using Jackknife bias correction and Recursive mean adjustment method. The Jackknife and recursive methods allow for small sample time series bias corrections and are adopted to check the robustness of the analyses.

According to the Dynamic Common Correlated Effects (DCCE) estimators, the lagged green technology innovations found to be a statistically significant positive influence on the current numbers of green technology innovations at a 5 percent significance level. This justifies that the dynamic nature of this model and implied that an increase in green technology innovations in the previous year motivates more green technology innovations in the following year.

In most works of literature, the economic growth proxy by GDP was found to incite green technology innovations (see Belin et al., 2011; Meirun et al., 2020). Interestingly, when we disentangle the GDP into different sectoral compositions, it shows ambiguous results. The agriculture values added exert a negative effect on green technology innovations based on mean group DCCE. It is demonstrated that a 1 percent increase in agriculture value-added will cause a reduction in green technology innovations by 0.2426 percent in mean group DCCE. Meanwhile, the coefficient of the industrial and services value-added demonstrated that with every 1 percent increase in industrial output and services output, the green technology innovations increase by 0.0995 percent and 0.1970 percent, respectively. The results suggesting that the expansion of industrial could promote green technology innovations and it is in line with Shao et al., (2016). Whilst, based on our limited knowledge, there are no studies that estimate the direct effect of services value-added on the green technology innovations, nonetheless, Lin and Ho (2008) claimed that improvement in technological, organizational, and environmental dimensions in logistics service has positive influences on the willingness to adopt green practices. The growth of the service sector was also agreed by numerous studies to motivate the adoption of energy-efficient technologies and renewable energy resources (see Hashmi et al.,2020; Yassin \& Aralas, 2020; Murshed et al.,2020).

In terms of tourism development, the empirical analysis reveals that the number of tourist arrival has a significantly positive impact on green technology innovations. Hence, every 1 percent increase in tourist arrival leads to a 0.1680 increase in green technology innovations. This finding contradicts the view of Liu et al. (2017)

On the other hand, carbon emission and urbanization were found to significantly positive influence on green technology innovations. Empirically, it demonstrated that as carbon emission and share of urban population rise by 1 percent, the green technology innovations increase by 0.039 percent and 0.063 percent, respectively. The positive association between carbon emissions and green technology innovation parallel with Lin and Zhu (2019) but 


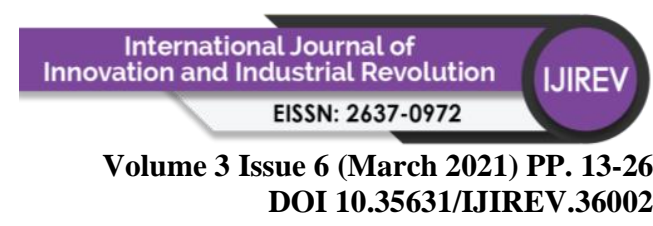

contrary to Yii Yii and Geetha (2017). Meanwhile, the existing studies rarely relate the urbanization and green technology innovations, however, opposing to this study, Zhou et al. (2020) believed that urbanization has negative influences on ecological efficiency in all aspects including sustainable technology.

For robust check, the results of the estimation of Jackknife bias correction and the Recursive mean adjustment method implied that there is no small sample time series bias on the sample. The sign and significant levels of all variables are consistent with the results in Mean Group Dynamic Common Correlated Effect (MG-DCCE), which indicates that the main estimation results are robust.

Next, based on the results, the CD statistics and its P-value that test for the cross dependencies show that the result does not reject the null hypothesis which claimed that the error terms are weakly cross-sectional dependence ( $p$-value $>0.005$ ). The value of goodness-of-fit measures (R-square) for all models indicates the model explains 51 percent of the cross-country variation for the mean group DCCE, 49 and 47 percent if consider the Jackknife bias correction and Recursive mean adjustment method, respectively.

Table 3: Result Estimation for DCCE Estimators for Asia's Middle-Income Countries

\begin{tabular}{|c|c|c|c|}
\hline \multicolumn{4}{|c|}{ Dynamic Common Correlated Effects (DCCE) } \\
\hline Variable & $\begin{array}{c}\text { Mean Group } \\
\text { (MG) }\end{array}$ & $\begin{array}{c}\text { Jack-knife } \\
\text { Bias } \\
\text { Correction } \\
\end{array}$ & $\begin{array}{c}\text { Recursive mean } \\
\text { adjustment } \\
\text { method }\end{array}$ \\
\hline $\operatorname{In} G T e c h_{\mathrm{it}-1}$ & $\begin{array}{c}0.2410 * * \\
(0.4499)\end{array}$ & $\begin{array}{l}0.1393 * * \\
(0.0495)\end{array}$ & $\begin{array}{c}0.1421^{* *} \\
(0.1260)\end{array}$ \\
\hline Argiculture Value added $(\ln A G R I)$ & $\begin{array}{c}-0.2426 * * \\
(0.804)\end{array}$ & $\begin{array}{c}-0.9015^{*} \\
(0.137)\end{array}$ & $\begin{array}{l}-0.910 * \\
(0.2987)\end{array}$ \\
\hline Industry Value added (lnINDU) & $\begin{array}{c}0.0995 * * \\
(0.0624)\end{array}$ & $\begin{array}{c}0.0186^{* *} \\
(0.0845)\end{array}$ & $\begin{array}{l}6.356 * * \\
(0.0364)\end{array}$ \\
\hline Services Value added (InSERV) & $\begin{array}{l}0.1970 * * \\
(0.0725)\end{array}$ & $\begin{array}{c}0.1951 * * \\
(0.066)\end{array}$ & $\begin{array}{c}0.1986 * * \\
(0.0839)\end{array}$ \\
\hline Tourism Arrival $(\ln T A)$ & $\begin{array}{c}0.1680 * * \\
(3.199)\end{array}$ & $\begin{array}{c}0.423^{*} \\
(0.2840)\end{array}$ & $\begin{array}{c}0.4860 \\
(0.3104)\end{array}$ \\
\hline Carbon emissions (lnCO2) & $\begin{array}{l}0.0390^{*} \\
(0.3207)\end{array}$ & $\begin{array}{c}0.0442 * * \\
(0.1343)\end{array}$ & $\begin{array}{c}0.0497 * * \\
(0.1127)\end{array}$ \\
\hline Urbanization $(\ln U R B)$ & $\begin{array}{l}0.0632 * \\
(0.1239) \\
\end{array}$ & $\begin{array}{c}0.3055^{* *} \\
(0.1818)\end{array}$ & $\begin{array}{c}0.4120 * * \\
(0.2255)\end{array}$ \\
\hline Constant & $\begin{array}{r}20.41 * * \\
(14.79)\end{array}$ & $\begin{array}{c}5.9216^{* * * *} \\
(10.24)\end{array}$ & $\begin{array}{c}9.2187 * * * \\
(10.07)\end{array}$ \\
\hline Obs. & 440 & 440 & 420 \\
\hline$R$-squared & 0.51 & 0.49 & 0.47 \\
\hline $\begin{array}{c}\text { CD Statistic } \\
(p \text {-value })\end{array}$ & $\begin{array}{c}-0.52 \\
(0.244)\end{array}$ & $\begin{array}{c}-0.42 \\
(0.392)\end{array}$ & $\begin{array}{c}-9.42 \\
(0.210)\end{array}$ \\
\hline
\end{tabular}

Notes: The dependent variable is the green technology innovation $(\operatorname{lnGTech).~All~variables~are~expressed~}(*)$ significant at the 10 percent level, $(* *)$ significant at 5 percent level, and $(* * *)$ significant at the 1 percent level. The analysis uses dynamic common correlated effects estimation developed by Chudik and Pesaran (2015). Figure Copyright (C) GLOBAL ACADEMIC EXCELLENCE (M) SDN BHD - All rights reserved 


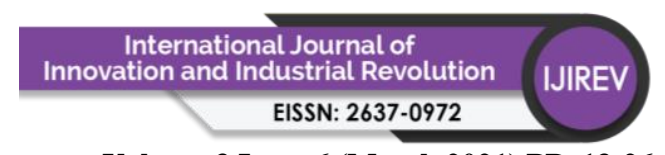

Volume 3 Issue 6 (March 2021) PP. 13-26

DOI 10.35631/IJIREV.36002

in parentheses is the standard error, Cross-Sectional Dependence (CD) test which is p-value and the null hypothesis is that the error terms are weakly cross-sectional dependent.

\section{Concluding Remarks}

This paper provides new empirical evidence on the effects of sectoral composition on green technology innovations in 20 selected Asia's Middle-Income countries from 1995 until 2016. Moreover, while most of the macro panel data is still dominated by the estimators primarily by Arellano and Bond (1991) and Blundell and Bond (1998), this paper breaks new ground by adopting the Dynamic Common Correlated Effect (DCCE) estimator to capture the potential existence of cross-section dependence due to common stock and interdependencies, heterogeneity across Asia's Middle-Income countries.

First, the finding reveals that the expansion of industry and services sectors including tourism promotes green technology innovations. In terms of the industrial sector, the government initiative and intensity of environmental regulation to solve the environmental issues has stimulated the industrial transformation and eventually leading to motivates more adoption of environmental technology (Liu et al., 2016). Concurrently, according to Aithal and Jeevan (2016), there is a greater need for the services to go more sustainable and greener, thus, increases the demand for green technologies in the services sector. On the other hand, the greening the tourism industry initiative has motivated tourist operators to adopted energyefficient operations and efficient waste management, hence motivates greener innovations (Gavrilovic and Maksimovic, 2018). Nonetheless, the negative association between agriculture and green technology innovations implied that the agriculture sector has not played a significant role yet in promoting environmental innovation.

Following our empirical results, urbanization and environmental quality also important determinant for green technology innovations. Urbanization becomes the driving force for highly skilled migrants flow to the urban area have a positive effect on urbanization innovation output (Lyu et al.,2019). From a theoretical point of view, the urban environmental transition theory postulated that the process of urbanization not only increases the wealth of these cities but also improves environmental regulation and technology innovation (Poumanyvong \& Kaneko, 2010). Meanwhile, the results also indicate that technological innovation responds actively to carbon emissions.

The finding in the current study may have several policy implications. First, the governments in Middle-Income countries should emphasise the adoption and application of green technology in all sectors including the agriculture sector to stimulating demand for green technologies. In the case of agriculture, the government plays important role in stimulating environmental awareness among producers and farmers and facilitating the sharing of technologies and innovations. These sectoral-wise differences should be considered otherwise the policymakers may be misguided about the implications. Second, as middle-income countries continue to catch up with advanced countries, they will be emitting more carbon dioxide (Guo et al.,2020). Moreover, according to Yassin et al.,(2021), as the tourism density increases, the ability of countries to reduce environmental stress decreases. Hence, a comprehensive framework is needed to facilitate green technology innovation to become the main key driver of modernisation and environmental assurance for middle-income countries. Third, proper design and planning for sustainable lifestyles for the rural and urban population are needed in middle-income countries which encourages more demand for environmentally 


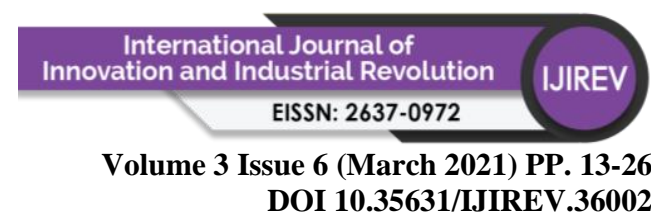

friendly products and technology, thus stimulate the private enterprise's motivation to invest in environmental $\mathrm{R} \& \mathrm{D}$ and innovation.

Surely, this study has few limitations. The study only includes 20 selected Asia's MiddleIncome countries as data from some countries are missing. Other than that, the baseline data only allow for macro-level assessment instead of the corresponding individual or firm level. For this reason, future researchers can extend this current study to other regions or lower and high-income countries. Further research based on the firm-level study may help to broaden the knowledge and helping the policymaker to formulate and create more precise economics and environmental policy.

\section{References}

Aithal, P. S., \& Jeevan, P. (2016). How Service Industries Can Transform Themselves into Green Business Industries. International Journal of Management Sciences and Business Research, 5(4), 150-168.

Anderson, F.N. and Karpestam, P. (2012). The Australian Carbon Tax: A Step In The Right Direction But Not Enough. Carbon Management. 3(3): 293 - 302.

Arellano, M., \& Bond, S. (1991). Some tests of specification for panel data: Monte Carlo evidence and an application to employment equations. The review of economic studies, 58(2), 277-297.

Asia Development Bank Institute. (2012). Policies and Practices for Low-Carbon Green Growth in Asia. 1 - 58.

Bekhet, H. A., \& Othman, N. S. (2017). Impact of urbanization growth on Malaysia CO2 emissions: Evidence from the dynamic relationship. Journal of cleaner production, 154, 374-388.

Belin, J., Horbach, J., \& Oltra, V. (2011). Determinants and specificities of eco-innovationsAn econometric analysis for the French and German industry based on the Community Innovation Survey (No. 2011-17). Groupe de Recherche en Economie Théorique et Appliquée (GREThA).

Blundell, R. and S. Bond (1998). Initial conditions and moment restrictions in dynamic panel data models. Journal of Econometrics, 87, 115-143

Cao, W., Zhang, Y., \& Qian, P. (2020). Correction: The Effect of Innovation-Driven Strategy on Green Economic Development in China-An Empirical Study of Smart Cities. Int. J. Environ. Res. Public Health 2019, 16 (9), 1520. International Journal of Environmental Research and Public Health, 17(10), 3380.

Chakraborty, S.K. and Mazzanti, M. (2020). Energy Intensity and Green Energy Innovation: Checking Heterogeneous Country Effects in the OECD. Structural Change and Economic Dynamics, 52: 328 - 343.

Chudik, A., \& Pesaran, M. H. (2015). Common correlated effects estimation of heterogeneous dynamic panel data models with weakly exogenous regressors. Journal of Econometrics, 188(2), 393-420.

Dogan, E., \& Inglesi-Lotz, R. (2020). The impact of economic structure to the environmental Kuznets curve (EKC) hypothesis: evidence from European countries. Environmental Science and Pollution Research, 27(11), 12717-12724.

Du, K., Li, P., \& Yan, Z. (2019). Do green technology innovations contribute to carbon dioxide emission reduction? Empirical evidence from patent data. Technological Forecasting and Social Change, 146, 297-303. 


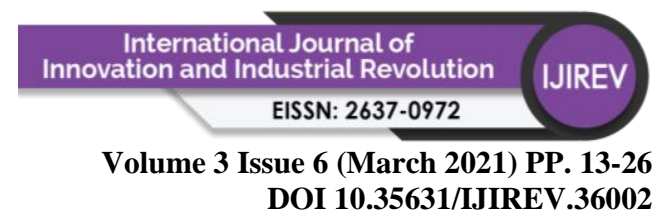

Faiers, A., Cook, M., and Neame, C. (2007). Towards a Contemporary Approach for Understanding Consumer Behaviour in the Context of Domestic Energy Use. Energy Policy. 35(8): $4381-4390$.

Fisher, A. G. (1935). Clash of progress and security. Macmillan and Co. Limited, London.

Gavrilović, Z., \& Maksimović, M. (2018). Green innovations in the tourism sector. Strategic Management, 23(1), 36-42.

Gryshova, I., Kyzym, M., Khaustova, V., Korneev, V., \& Kramarev, H. (2020). Assessment of the Industrial Structure and its Influence on Sustainable Economic Development and Quality of Life of the Population of Different World Countries. Sustainability, 12(5), 2072.

Guo, M., Nowakowska-Grunt, J., Gorbanyov, V., \& Egorova, M. (2020). Green technology and sustainable development: Assessment and green growth frameworks. Sustainability, 12(16), 6571.

Hashmi, S. H., Hongzhong, F., Fareed, Z., \& Bannya, R. (2020). Testing non-linear nexus between service sector and CO2 emissions in Pakistan. Energies, 13(3), 526.

Hoechle, D. (2007). Robust standard errors for panel regressions with cross-sectional dependence. The stata journal, 7(3), 281-312.

Karekezi, S., McDade, S., Boardman, B. and Kimani, J. and Lustig, N. (2012). Chapter 2 Energy, Poverty and Development. Cambridge University Press. pp $151-190$.

Lin, B., \& Zhu, J. (2019). Determinants of renewable energy technological innovation in China under CO2 emissions constraint. Journal of environmental management, 247, 662-671.

Lin, C. Y., \& Ho, Y. H. (2008). An empirical study on logistics service providers' intention to adopt green innovations. Journal of technology management \& innovation, 3(1), 17-26.

Liu, J., Zhang, J., \& Fu, Z. (2017). Tourism eco-efficiency of Chinese coastal cities-Analysis based on the DEA-Tobit model. Ocean \& coastal management, 148, 164-170.

Liu, W., Tong, J., \& Yue, X. (2016). How does environmental regulation affect industrial transformation? A study based on the methodology of policy simulation. Mathematical Problems in Engineering, 2016.

Lyu, L., Sun, F., \& Huang, R. (2019). Innovation-based urbanization: Evidence from 270 cities at the prefecture level or above in China. Journal of Geographical Sciences, 29(8), 1283-1299.

Maslyuk, S. and Dharmaratna, D. (2013). Renewable Energy Generation, CO2 Emissions and Economic Growth: Evidence from Middle-Income Countries in Asia. Estudios De Economia Aplicada. 31-1: 217 - 244.

Meirun, T., Mihardjo, L. W., Haseeb, M., Khan, S. A. R., \& Jermsittiparsert, K. (2020). The dynamics effect of green technology innovation on economic growth and CO 2 emission in Singapore: new evidence from bootstrap ARDL approach. Environmental Science and Pollution Research, 1-11

Mills, B. and Schleich, J. (2012). Residential Energy-Efficient Technology Adoption, Energy Conservation, Knowledge and Attitudes: An Analysis of European Countries. Energy Policy. 49: $616-628$.

Murshed, M., Nurmakhanova, M., Elheddad, M., \& Ahmed, R. (2020). Value addition in the services sector and its heterogeneous impacts on CO 2 emissions: revisiting the EKC hypothesis for the OPEC using panel spatial estimation techniques. Environmental Science and Pollution Research, 27(31), 38951-38973.

Narayan, P.K. and Smyth, R. (2008). Energy Consumption and Real GDP in G7 Countries: New Evidence from Panel Cointegration with Structural Breaks. Energy Economics. 30(5): $2331-2341$. 


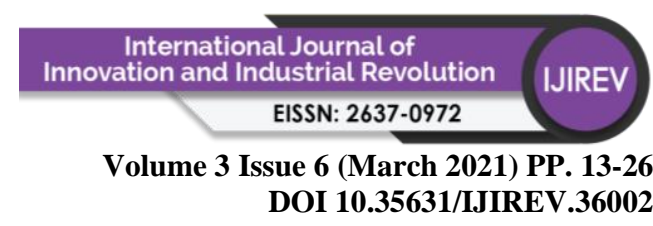

OECD (2020). Green Growth Indicators 2020: Patents in environment-related technologies $O E C D$. Retrieved from https://stats.oecd.org/index.aspx?queryid=29068 on December 2020.

Pesaran, M. H. (2007). A simple panel unit root test in the presence of cross-section dependence. Journal of applied econometrics, 22(2), 265-312.

Pesaran, M. H., Shin, Y., \& Smith, R. P. (1999). Pooled mean group estimation of dynamic heterogeneous panels. Journal of the American statistical Association, 94(446), 621634.

Poumanyvong, P. and Kaneko, S. (2020). Does Urbanization Lead to Less Energy Use and Lower $\mathrm{CO}_{2}$ Emissions? A Cross-Country Analysis. Ecological Economics. 70(2): 434 $-444$.

Poumanyvong, P., \& Kaneko, S. (2010). Does urbanization lead to less energy use and lower CO2 emissions? A cross-country analysis. Ecological Economics, 70(2), 434-444.

Saleem, H., Khan, M.B., Shabbir, M.S. (2020). The Role of Financial Development, Energy Demand and Technological Change in Environmental Sustainability Agenda: Evidence from Selected Asian Countries. Environmental Science and Pollution Research. 27: $5266-5280$.

Sohag, K., Mamun, M.A., Uddin, G.S. and Ahmed, A.M. (2020). Sectoral Output, Energy Use, and $\mathrm{CO}_{2}$ Emissions in Middle-Income Countries. Environmental Science and Pollution Research. 24: 9754 - 9764.

Shao, S., Luan, R., Yang, Z., \& Li, C. (2016). Does directed technological change get greener: empirical evidence from Shanghai's industrial green development transformation. Ecological Indicators, 69, 758-770.

Taghizadeh-Hesary, F. and Rasoulinezhad, E. (2020). Analyzing Energy Transition Patterns in Asia: Evidence from Countries with Different Income Levels. Frontiers in Energy Research. 8(162): 1 - 13.

Taghizadeh-Hesary, F., Rasoulinezhad, E., Yoshino, N., Chang, Y., Taghizadeh-Hesary, F., and Morgan, P.J. (2020). The Energy-Pollution-Health Nexus: A Panel Data Analysis of Low-and Middle-Income Asian Countries. The Singapore Economic Review. 1 -21 .

Tatsutani, D.A.M. (2009). Sustainable Energy for Developing Countries. Surveys and Perspectives Integrating Environment and Society. 2(1): 1 - 16.

Usman, M., Kousar, R., Yaseen, M.R. and Makhdum, M.S.A. (2020). An Empirical Nexus between Economic Growth, Energy Utilization, Trade Policy, and Ecological Footprint: A Continent-Wise Comparison in Upper-Middle-Income Countries. Environmental Science and Pollution Research. 27: 38995 - 39018.

Wang, S., Zhou, D.Q., and Wang, Q.W. (2011). CO Emissions, Energy Consumption and Economic Growth in China: A Panel Data Analysis. Energy Policy. 39(9): 4870 - 4875.

Wang, Y., Chen, L., and Kubota, J. (2016). The relationship between urbanization, energy use, and carbon emissions: evidence from a panel of Association of Southeast Asian Nations (ASEAN) countries. Journal Cleaner Production. 112(2):1368-1374

World Bank. 2020. World development indicators. Group. Retrieved from https://databank.worldbank.org/source/world-development-indicators on December 2020

Yanikkaya, H. (2003). Trade Openness and Economic Growth: A Cross-Country Empirical Investigation. Journal of Development Economics. 72(1): 57 - 89.

Yassin, J., \& Aralas, S. (2020). The Service Sector and Carbon Emission Nexus: Revisiting Environmental Kuznets Curve. Jurnal Ekonomi Malaysia, 54(2): 113 - 124 
Volume 3 Issue 6 (March 2021) PP. 13-26 DOI 10.35631/IJIREV.36002

Yassin, J., Aralas, S., \& Basa, D. E. (2021). Tourism Density Effect on Environmental Performance Index: Evidence in ASEAN Countries. Applied Environmental Research, 43(1), 90-101.

Yii, K. J., \& Geetha, C. (2017). The nexus between technology innovation and CO2 emissions in Malaysia: evidence from granger causality test. Energy Procedia, 105, 3118-3124.

Zhou, Y., Kong, Y., Wang, H., \& Luo, F. (2020). The impact of population urbanization lag on eco-efficiency: a panel quantile approach. Journal of Cleaner Production, 244, 118664. 